\title{
Social Practice of Sahabat Kapas in Vulnerable Children and Children with Special Condition Assistance in Surakarta
}

\author{
Nurul Istiqomah 1,* (D) Bagus Haryono 2, (D) and Argyo Demartoto 2 \\ ${ }^{1}$ Master of Sociology, Faculty of Social and Political Sciences, \\ Universitas Sebelas Maret, 57126, Surakarta, Indonesia \\ 2 Department of Sociology, Faculty of Social and Political Sciences, \\ Universitas Sebelas Maret, 57126, Surakarta, Indonesia \\ * Corresponding Author: nuriesqomah@gmail.com
}

\section{ARTICLE INFO}

Publication Info:
Research Article

How to cite:

Istiqomah, N., Haryono, B., $\mathcal{E}$

Demartoto, A. (2020). Social

Practice of Sahabat Kapas in

Vulnerable Children and Children with Special Condition Assistance in Surakarta. Society, 8(2), 390402.

DOI: 10.33019/society.v8i2.196

Copyright (C) 2020. Owned by Author(s), published by Society

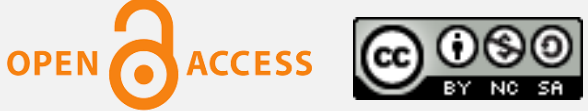

This is an open-access article.

License: Attribution-

NonCommercial-ShareAlike (CC BY-NC-SA)

\begin{abstract}
Vulnerable Children and Children with Special Condition (Anak-Anak dalam Kondisi Khusus dan Rentan or AKKR) are children who must receive assistance and motivation to achieve their rights. In practice in real life, they are temporarily forced to be in correctional institutions/detention centers/Institute for Special Development Children (LPKA) as a result of violating the law. It should not make them shunned, but instead, they must be assisted. Vulnerable Children and Children with Special Condition need enforcement of the fulfillment of their rights. The existence of Sahabat Kapas as a nonprofit nongovernmental organization (NGO) located in Karanganyar, Central Java, Indonesia, provides concerns and solicitudes for Vulnerable Children and Children with Special Condition. This research aims to analyze and describe the forms of social practice based on habitus in Sahabat Kapas organization. This research used a qualitative research method with Bourdieu's genetic structuralism approach. Informants were determined using purposive sampling techniques. Data collection was performed using participant observation techniques in the field, in-depth interviews, and documentation studies. Data were analyzed in three stages, including data reduction, data presentation, and ended with concluding. Data were verified by source triangulation. The results showed that Sahabat Kapas became an alternative to assist Vulnerable Children and Children with Special Condition conducted in correctional institutions/detention centers/Institute for Special Development Children (LPKA). The social practices conducted by Sahabat Kapas in assisting Vulnerable Children and
\end{abstract}

Copyright (C 2020. Owned by Author(s), published by Society. This is an open-access article under the CC-BY-NC-SA license. 
Received: June 14, 2020;

Accepted: August 3, 2020;

Published: August 31, 2020;
Children with Special Condition are following the capital they have and the history of the habitus they conduct. Relational social capital is at stake by assistants with prison officers and how to build relationships with children. Economic capital refers to the efforts made by Sahabat Kapas to get funds to support assistance through entrepreneurship and opening donations. Cultural capital includes the whole intellectual/knowledge gained by assistance through training that is useful to assist children in correctional institutions/detention centers/Institute for Special Development Children (LPKA). Symbolic capital is manifested in the form of awards from the government for Sahabat Kapas and assistance awards for children in the form of gifts.

$\begin{array}{ll}\text { Keywords: } & \text { AKKR; Assistance; Children with Special } \\ & \text { Condition; NGO; Sahabat Kapas; Social } \\ & \text { Practice; Vulnerable Children }\end{array}$

\section{Introduction}

Children are the most precious gift from God for each family. Those who are vulnerable and often become victims of violence perpetrated by parents, the community, and peers, are considered weak figures. The child dependency rate is still high on the family and environment to fulfill their basic rights. According to the Directorate-General of Corrections (DGC) Ministry of Law and Human Rights of the Republic of Indonesia, the number of children in the Institute for Special Development Children (Indonesian: Lembaga Pembinaan Khusus Anak or LPKA) is increasing annually, as follows:

Table 1. Number of Children in Conflict with the Law (CCL) in Indonesia

\begin{tabular}{|c|c|}
\hline Year & Number of Cases \\
\hline 2015 & 2,270 Cases \\
\hline 2016 & 2,319 Cases \\
\hline 2017 & 2,446 Cases \\
\hline 2018 & 2,932 Cases \\
\hline 2019 & 3,568 Cases \\
\hline
\end{tabular}

Source: Direktorat Jenderal Pemasyarakatan Kementerian Hukum dan Hak Asasi Manusia Republik Indonesia (2020)

According to Article 1 Paragraph 1 of Laws of the Republic Indonesia, Number 35 of 2014 concerning Amendments to Laws of the Republic Indonesia Number 23 of 2002 concerning Child Protection, "Child is someone who is not yet 18 (eighteen) years old, including children who are still in the womb" (Republik Indonesia, 2014). Whereas according to Article 1 of the United Nations Convention on the Rights of the Child (UNCRC), "For the purposes of the present Convention, a child means every human being below the age of eighteen years unless under the law applicable to the child, majority is attained earlier" (United Nations, 1989). The Convention on the Rights of the Child by the Republic of Indonesia was ratified through 
Presidential Decree, Number 36 of 1990. “With reference to the provisions of Articles 1, 14, 16, 17, 21, 22 and 29 of this Convention, the Government of the Republic of Indonesia declares that it will apply these articles in conformity with its Constitution" (Presiden Republik Indonesia, 1990).

Vulnerable Children and Children with Special Condition (Indonesian: Anak-Anak dalam Kondisi Khusus dan Rentan or AKKR) who are in conflict with the law in various cases and forced to undergo sanctions or punishment in correctional institutions/detention centers/LPKA are not suspects. They are victims of violence perpetrated by parents, the community, and peers. Those who are forced to undergo punishment in prison remain children who need attention and assistance. Yayasan Sahabat Kapas (Sahabat Kapas Foundation), or known as Sahabat Kapas, is a legal entity registered in the Ministry of Law and Human Rights of the Republic of Indonesia based on Ministerial Decree Number AHU-367.AH.10.04 of 2010. The management and assistants of Sahabat Kapas consist of people who are sensitive to the needs of children who are temporarily forced to be in correctional institutions/detention centers/LPKA (Sahabat Kapas, 2019b).

Children who are in Surakarta Class I Detention Center, located in Central Java Province, Indonesia, are AKKR who conflict with the law in various cases and forced to undergo sanctions or punishment. Class I Detention Center in Surakarta consists of children from various regions in Central Java Province, Indonesia, such as Karanganyar, Wonogiri, Boyolali, and Surakarta. Cases of children in Surakarta Class I Detention Center have increased from year to year, as follows:

Table 2. Number of Children in Conflict with the Law (CCL) in Surakarta Class I Detention Center

\begin{tabular}{|c|c|}
\hline Year & Number of Cases \\
\hline 2017 & 624 Cases \\
\hline 2018 & 645 Cases \\
\hline 2019 & 688 Cases \\
\hline 2020 & 552 Cases \\
\hline
\end{tabular}

Source: Direktorat Jenderal Pemasyarakatan Kementerian Hukum dan Hak Asasi Manusia Republik Indonesia (2020)

Data on cases of children in Surakarta Class I Detention Center is not a small number, it is necessary to have an action taken by Sahabat Kapas in helping to fulfill the rights of the child. Children in detention need help from various parties, both from the government and the private sector. Actions taken by Sahabat Kapas are an act of concern for children in detention centers.

\section{Literature Review}

Sahabat Kapas office is located on Jalan Jambu II No. 36 RT 09 RW 04 Pondok Tohudan, Colomadu, Karanganyar, Central Java Province, Indonesia (Sahabat Kapas, 2019b). The service areas of Sahabat Kapas are the ex-residency of Surakarta (Surakarta, Klaten, Wonogiri, Sragen, Boyolali, Sukoharjo, and Karanganyar), which focuses on Wonogiri Detention Center, Surakarta Detention Center, Klaten Correctional, and Kutoarjo Institute for Special Development Children (Sahabat Kapas, 2019a). Since August 2009 until today, Sahabat Kapas have assisted 127 boys and 2 girls in Vulnerable and Special Conditions.

Copyright (C 2020. Owned by Author(s), published by Society. This is an open-access article under the CC-BY-NC-SA license. 
Assistance provided by Sahabat Kapas Foundation is a distribution, in which the distribution cannot be interpreted narrowly. In a social context, distribution is the practice of allocating and sharing something usually contested or valuable. The concept of the arena or field according to Bourdieu is a competitive market that has various types of capital, including social, economic, cultural, and symbolic capital that can be used and utilized (Ritzer \& Goodman, 2012, p. 583, as cited in Fatmawati, 2020). The concept of Habitus and Field: (Habitus $\mathbf{x}$ Capital) + Field $=$ Social Practice .

\subsection{Habitus}

Habitus is mental or cognitive structures (Ritzer \& Goodman, 2014, p. 903) with which people relate to the social world. Habitus describes a set of tendencies that encourage social actors or actors to act and react in certain ways. Habitus is a product of history, as a legacy from the past which is influenced by the existing structure. Habitus is a product of history that creates individual and collective actions and accordingly conforms to the patterns evoked by history. Individual habits are obtained through their life experiences and have certain functions in the history of the social world in which they occur. Individual life experiences obtained from historical results are then internalized within and used to feel, understand, realize, and assess the social world. It is through these patterns that individuals produce their actions and also judges them (habitus controls the thoughts and choices of individual actions) (Ritzer \& Goodman, 2003, p. 522).

A habitus is obtained as a result of long-term work in a position in the social world. Thus, habitus varies depending on where and how someone's position in the world because not everyone has the same habitus. However, people who occupy the same position in the social world tend to have the same habitus. In this sense, habitus can also be a collective phenomenon (Ritzer \& Goodman, 2003, p. 522). The existence of various kinds of habitus means that the social world and its structures do not force themselves uniformly on all actors.

Habitus can be lasting and can also change, in the sense that it can be transferred from one arena to another. Although habitus is a legacy of experience or a product of structural internalization, habitus can change according to the arena in which it is located. However, people with improper habitus are often called Bourdieu as hysteresis.

Habitus produces, also produced by the social world. On the one hand, habitus is a "structured structure" meaning, habitus is a structure that compiles the social world. On the other hand, habitus is a "structured structure" meaning, habitus is a structure composed of the social world. In other words, Bourdieu describes habitus as the dialectic of internalizing externalities and externalizing internalities (Ritzer \& Goodman, 2003, p. 523). According to Bourdieu, it is a practice that mediates between habitus and the social world. On the one hand, through the practice of habitus created; and on the other hand, the social world was created from the results of practice.

Although habitus is an internalized structure that limits thought and choice of action, it does not determine it (Ritzer \& Goodman, 2014, p. 905). Habitus only suggested what actors in the social world should think and do. In determining choices, actors use in-depth consideration that is conscious of choices, even though the decision-making process reflects the role of habitus. The concept of habitus Bourdieu has an important role in this research to find out how a NonGovernmental Organization (NGO) assists Vulnerable Children and Children with Special Condition, what their conditions are before and after getting assistance from Sahabat Kapas. What habits are conducted by assistants of Sahabat Kapas for these children are mainly intending to return the joy and happiness of children. 


\subsection{Field}

Bourdieu argued that the field is a social network between objective propositions in a social order that emerged separate from individual consciousness and will (Ritzer \& Goodman, 2012, p. 582). The field is intended as a special space within the community, in which there is an effort to fight for resources (capital) and also for the sake of gaining particular access close to the power hierarchy. The field can also be interpreted as a type of competitive open market, where various kinds of capitals, including economic, cultural, social, and symbolic capitals are available.

Competition happens to get more sources so that the difference between one agent with another. The more resources you have, the higher the structure you have. These differences provide a social hierarchical structure and gain legitimacy as if it were a scientific process. The field in this research is the field of assistance. Vulnerable Children and Children with Special Condition assistance who are in correctional institutions/detention centers/LPKA, this is due to the limitations of children to access the outside world of detention. The distribution of the arena by Sahabat Kapas in assisting children is a social practice that allows the involvement of various parties.

\subsection{Capital}

Capital is obtained when someone has the right habitus. The exact ownership of habitus and capital provides a greater opportunity to succeed in the field. The position as an actor to succeed in the field is determined by the relative amount and weight of capital owned. These capitals enable actors to control their and other actors' destiny. According to Bourdieu, there are four classifications of capital, including:

1) Social capital, which includes relationships or social networks owned by actors (individuals or groups) related to other parties. This capital is the amount of existing and potential resources. Social capital is also manifested in the form of social relations carried out by individuals in a social environment. The relationship is closely intertwined with the existence of a reliable social network.

2) Economic capital refers to the channel of funds or material obtained that can be used for all purposes to be achieved. Agencies compete with each other for economic capital through various investment strategies using the accumulation of economic capital. Discusses habitus about economic capital obtained by Sahabat Kapas to support the assistance of children in detention centers such as donations and the "Onjel" Program (fundraising program as well as the product's brand managed by Sahabat Kapas). Because with donations and the "Onjel" Program, it will help to support the process of assisting children so that their basic rights can be fulfilled. While this is not based on government or state funds.

3) Cultural capital includes all intellectuals that can be produced through formal or nonformal education. This capital is related to the position of someone who is inseparable from power in symbols.

4) Symbolic capital includes all forms of prestige, status, authority, and legitimacy (Bourdieu, 2012, p. 67).

Capital owned by Sahabat Kapas in assisting Vulnerable Children and Children with Special Condition in correctional institutions/detention centers/LPKA consists of the following capital:

1) Social Capital. This capital is owned by each assistant who will carry out rehabilitation of children in detention centers. The assistant knows the training process. This capital is used

Copyright (C 2020. Owned by Author(s), published by Society. This is an open-access article under the CC-BY-NC-SA license. https://doi.org/10.33019/society.v8i2.196 
to communicate with prison officials so that permission is given for assistance. Besides, the assistants also establish communication with children, the diverse conditions of children are a challenge for the assistants. Therefore, social capital is important for assistants in carrying out social practices.

2) Economic Capital. Capital owned by Sahabat Kapas is obtained from entrepreneurship called the "Onjel" Program. From here, income can be obtained to encourage the sustainability assistance of Vulnerable Children and Children with Special Condition. Besides, there are open donation activities carried out through Sahabat Kapas website.

3) Cultural Capital. This capital includes all intellectuals produced through education or training. Assistants who do not yet have the stock of knowledge to enter the detention center will be given several training sessions on material following the module. Formal training is opened once a year. Before assisting, a case assessment from a child is held to facilitate the selection of material to be used.

4) Symbolic Capital. This capital shows the authority of Sahabat Kapas who has obtained permission from the detention/prison officer in assisting. The assistant has the power to rehabilitate children in the prison. However, it does not limit children to get their rights such as picket in the detention center, meeting family, and so on.

Capital owned by Vulnerable Children and Children with Special Condition in detention/prisons is social capital and cultural capital. For social capital, children have social capital embeddedness. For those who can adapt to the assistants of Sahabat Kapas, it will be easier to re-integrate with their environment. For children who have a quiet nature and do not want to talk at all tend to be slower to re-integration. For cultural capital, children who get assistance by being given special material following the case experienced will open their way of thinking to be wiser. Knowledge is given by the assistant through individual counseling, group counseling, and large class discussions. They are invited to empathize with the victims and feel it.

This research used Bourdieu's theory of social practice to find out how social practices are in assisting the Vulnerable Children and Children with Special Condition conducted by Sahabat Kapas. The practice carried out by Sahabat Kapas in assisting children aims to provide new habits and encourage children to be able to adapt. The child has self-strong capital with the assistance of Sahabat Kapas, through the provision of assisting material which is done once a week. The presence of Sahabat Kapas also provides capital to support the Vulnerable Children and Children with Special Condition.

\section{Research Methodology}

This research used a qualitative method with a descriptive technique which is a research that tends to be more in-depth, with the research strategy of a case study. This research focuses on Yayasan Sahabat Kapas and its activities and was conducted in March 2020. Bourdieu stated that social action cannot be merely defined as a product of a series of external rules. The rules are those that arise from the socialization process (Lee, 2006). Informants, who were considered relevant to the criteria and were still actively assisting in Sahabat Kapas, were selected using a purposive sampling technique. This technique was performed by determining the informant, which consists of Director of Sahabat Kapas as a key informant, psychologist staff and administrative staff as the main informants, and volunteers as the supporting informants. It aims to obtain trusted information for accountability in research results. 
Data collection techniques in this research were conducted in two ways, which consist of primary and secondary data. Primary data was conducted using informant observation techniques in the field and in-depth interviews. Meanwhile, secondary data obtained from literature and documentation studies. The data analysis technique is an interactive analysis that starts with data reduction, data presentation, and ends with concluding (Miles \& Huberman, 2007). Data reduction was done by reducing the data as needed in this research concerning the research objectives. Subsequently, a data presentation was made related to social practices in Sahabat Kapas in assisting Vulnerable Children and Children with Special Condition. Finally, data verification was carried out through the triangulation of sources, and conclusions were drawn from all data that has been reviewed in the research.

\section{Results and Discussion}

\subsection{Habitus of Assistance for Vulnerable Children and Children with Special Condition}

According to Pierre Bourdieu, habitus is obtained through repeated practice or learning causes it to be pre-conscious (Mutahir, 2011, p. 58, as cited in Nurdiansyah, 2016, p. 4). The process carried out repeatedly applied by the environment of each subject of this research forms a persistent and strong habitus for assistants in Sahabat Kapas by creating all kinds of programs for the achievement of the objectives of assisting Vulnerable Children and Children with Special Condition (Anak-Anak dalam Kondisi Khusus dan Rentan or AKKR). The process of recognition or rehabilitation performed by Sahabat Kapas is carried out repeatedly through counseling given by the assistance or psychologist, in which the counseling is done individually or in groups. Individual counseling is performed based on the individual's needs, while group counseling is conducted at a maximum of 13 meetings. Therefore, children understand even at the same time enjoy the way or process conducted by Sahabat Kapas.

The environment around prisons/detention centers and the will within individuals or groups encourage the subjects to become or form an atmosphere of pleasant assistance to fulfill children's rights. In addition to forming comfort, love, and enjoyment of programs conducted, such as play, the environment created between the children and the assistance can shape the children's interest so the children become cheerful and can get rid of their problems in the past.

\subsection{The Field of Sahabat Kapas}

The field is a social space that refers to the whole social life (Bourdieu, 2010). In the context or scope of Sahabat Kapas as an organization, the field is considered as a place where individuals fight over various forms of capital, from social, economic, cultural, to symbolic capitals. According to Bourdieu, in the field, there is an effort to struggle for resources to achieve or obtain a position in the field (Mutahir, 2011, p. 54, as cited in Nurdiansyah, 2016, p. 4). Fighting the filed produces a dynamic structure without the awareness of the individuals within it. In this case, Sahabat Kapas has the field of an event or program that is held, such as 1) Program for children assistance in detention centers in four locations, which consist of the Wonogiri Detention Center, Surakarta Detention Center, Klaten Correctional, and Kutoarjo Institute for Special Development Children. Regarding the physical field, this assistance is conducted to provide motivation or encouragement for children to remain cheerful in achieving their future goals. 2) "Onjel" Program is aimed at raising funds to increase child assistance and campaigning on children's issues through creative programs. 3) Reintegration is an activity conducted by Sahabat Kapas to assist children when they are released or post-free. The program is focused on preparing families and the environment to make children remain comfortable, providing better access to education, training, and work opportunities. 4) The 
promotion of children's rights is conducted by socialization in Community School (a collaborative activity between Sahabat Kapas, Klaten Institute for Special Development Children, Yayasan Setara, UNICEF, and Agency of Surakarta for Community Empowerment, Women's Empowerment, Child Protection, and Family Planning) (Sahabat Kapas, 2015) and social media. There are interrelated structures within the field that place individuals in a social position. According to Bourdieu, "habitus underlies the field and the capital owned by each place them into an interconnected structure between its positions" (Bourdieu, 2012, p. 12).

\subsection{The Capital Contention in the Field}

Every program in Sahabat Kapas has the socio-economic structure of diverse groups. An existing program in an organization would require considerable economic capital. Groups that have economic capital are those consisted of workers who fund the needs of activities through open donations. In this case, those who are willing to support the assistance of Vulnerable Children and Children with Special Condition can give their donations.

Besides, the economic capital also obtained through "Onjel" Program, which aims to increase efforts to assist Vulnerable Children and Children with Special Condition in the form of entrepreneurship and campaign on child issues. The profits of the sales from this program are used to support each of the assistance programs of Vulnerable Children and Children with Special Condition. Another form of economic capital is to prepare the overall tools used for socialization. Economic capital generated from Sahabat Kapas will later be channeled in the form of assisting equipment such as holding training every once a year, purchasing paper for children's games in detention/prisons, transportation costs for the assistants, and child counseling equipment. So that children get maximum assistance from Sahabat Kapas.

Social capital aims to make the social network that occurs between the assistant and the children to be safe and comfortable to returns children's joy and create new happiness. Sahabat Kapas and their staffs need to build trust in children. Trust is a product of good social capital. The existence of good social capital is marked by the presence of a solid social organization and creates a harmonious life.

"The biggest encouragement that develops Kapas (Sahabat Kapas) is the smile of children in prison. After we meet them, there must be a sense of addiction wanting to return to their activities again. Therefore, the smile doesn't disappear. The smile represents their happiness and passion. This is what makes us all in Kapas always eager to back and learn with them" (Interview, Dian Sasmita, Founder of Sahabat Kapas, May 15, 2020).

Social capital was obtained by the assistants of Sahabat Kapas through the training process. Training is conducted once a year and role play was conducted before entering the detention center. This is done to establish good communication with children in detention centers and officials in detention centers. An assistant who can communicate with children will make it easier for children to reintegrate, be confident, and be ready to return to the community when they are free from detention. The communication created between the child and the assistant of Sahabat Kapas is conducted through several stages, first, the introduction of the child with the assistant, secondly, with catharsis at this stage, the child is invited to tell anything about himself, about what happens inside, and thirdly, children are invited to play together, at this stage one can also capture material delivered by the assistant. This capital needs hard work if the assistant is confronted with a child who tends to be quiet. Quiet children need a special

Copyright (C) 2020. Owned by Author(s), published by Society. This is an open-access article under the CC-BY-NC-SA license. https://doi.org/10.33019/society.v8i2.196 
psychologist to consult with so that the handling of children is appropriate. Adaptable children will find it easier to return cheerful and happy.

Cultural capital is channeled through knowledge owned by children's assistant. It is done during the socialization of children in detention/prison centers. In this case, Yayasan Sahabat Kapas has strong cultural capital. Each assistant has good communication skills with children through individual and group counseling. When communicating, the language used is interesting and following the needs of children, so that they become cheerful again.

The knowledge possessed by the assistant is channeled to children through individual counseling. Individual counseling is given to each child with special indications following reports from the assistant and prison staff and children's willingness in counseling. Counseling material provided to children following the modules implemented by Sahabat Kapas. Individual counseling is given as long as the child is still in the detention center continuously, while group counseling is only given to children who have been selected or grouped by case. This group counseling cannot be given by just any assistants; only experienced assistants can provide group counseling.

Group counseling consists of at least 5 children and a maximum of 10 children. Group counseling consists of 13 sessions and is further divided into several sub-sessions and stages: the first stage is an introduction; the second stage is the child catharsis rooms, where children can vent feelings, continue to have gender recognition, health, and then establish healthy communication, then a new adjustment stage, and an assimilation stage. The whole material given to children gives different effects on children. Some children tend to be more aggressive, in the sense that children can recover quickly and be able to communicate with assistants more closely. Some children tend to be more introverted and didn't talk too much.

This symbolic capital is demonstrated by the existence of power within the assistants of Sahabat Kapas. This capital shows the authority of Sahabat Kapas who has obtained permission from the detention/prison officer in assisting. The assistant has the power to conduct rehabilitation on children in detention. However, it does not limit children to get their rights such as picket in detention centers, meeting family, and so on. This symbolic capital is obtained by Sahabat Kapas through various events or programs held with the enthusiastic reception of the Minister of Law and Human Rights of the Republic of Indonesia. It proves that Sabahat Kapas is a representative institution of the government and community organizations that can participate to fulfill children's rights in detention/prison centers.

\subsection{The Practice of Struggle of Sahabat Kapas}

A result of the formulation of habitus, capital, and field in social practice is what ultimately determines whether Sahabat Kapas can get recognition and status from the government. In the field of Sahabat Kapas, the social practices of the founders and staff determine themselves. The assistance given to the children is determined by the children's condition whether they feel safe and comfortable. It is indicated by the big smile on their faces.

The habitus of children can later be used to measure whether they can be positive again with new norms or even vice versa, they will be negative. Social practices have essential characteristics so that these practices can work properly. A practice occurs because of space and time (Mutahir, 2011, as cited in Nurdiansyah, 2016). The struggle of Sahabat Kapas is not only limited to assisting children in prisons/detention centers but also regular monitoring and supervision to check and know the condition of post-free children. It is done through a reintegration program by focusing on family readiness in accepting the children, facilitating children by providing access to education, training, and employment opportunities. 
There are times when in carrying out these practices there is a shift due to the psychological condition of the child. Vulnerable Children and Children with Special Condition who are in Surakarta Class I Detention Center certainly need assistance following the case experienced. Children with psychic conditions that have improved will receive assistance as well. Conversely, children who are still experiencing pressure, it will be difficult to accept and tend to be more silent.

Thus, Sahabat Kapas have their habitus in assisting children in the field of detention/prison centers. It is explained by Finance (1994, p. 4) as cited by Badjuri \& Yuwono (2002) in the four program planning indicators of activity, including input, process, output, and outcome, as follows:

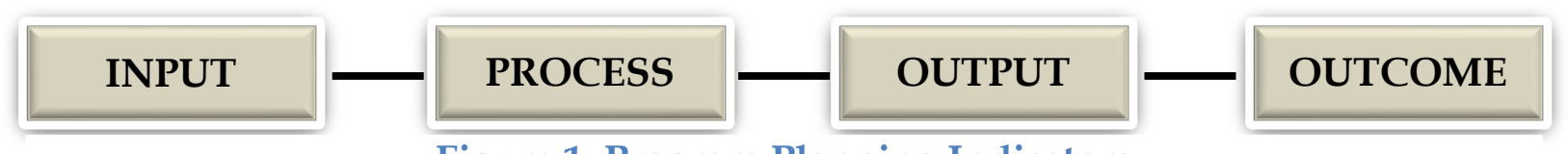

Figure 1. Program Planning Indicators

Source: Finance (1994) as cited by Badjuri \& Yuwono (2002)

Input can be seen from what is owned by Sahabat Kapas before conducted a process of assisting children. Sahabat Kapas has a vision, mission, strategic role, and mandate that underlie its establishment as a Non-Governmental Organization (NGO) that specializes in providing services to children, especially those who are vulnerable and in special condition according to the needs of each child. Sahabat Kapas categorizes the types of assistance by using various capitals, such as social, economic, cultural, and symbolic capital. In conducting its activities in the process of obtaining a good output, quality assistance is applied by holding the four capitals. In assisting, Sahabat Kapas provides individual or group counseling services. Counseling is done not only with the material, but also play in groups to make the children feel happy and cheerful again. Motivation is given individually and according to the needs of the children. Besides, there is a reintegration program, where children will be given the provision of knowledge and skills, as well as access to education that had previously been stopped. From the series of processes performed, it will produce the output or the immediate results. The output of the activities conducted by Sahabat Kapas is that the children will experience the previous or new condition. Every socialization material delivered by the assistants becomes knowledge or cultural capital for individual children. Thus, the level of children's trauma and children's attitudes become much better than before the assistance. The release of the children is done by preparing the family, as well as supervising the parents so that the children do not experience the same thing. The child grows and develops to be a more confident person and there are no obstacles in socialization with the community.

Outcome or the long-term effects of the process of activities performed in research in Sahabat Kapas show that it has been assisting Vulnerable Children and Children with Special Condition for eleven years. The outcome can be known from the supervision process conducted through parents or even the children come by themselves to Sahabat Kapas to tell stories or just play. Therefore, it can be seen that changes in behavior patterns exhibited by children have returned to the outside world for the sake of a good future. Labeling given by the community is a big obstacle for the children to return to the community. Hence, family readiness to look after children is required. The assistance provided creates character and education, coaching certificates that can be used after being released. 
Social Practice of Sahabat Kapas in Vulnerable Children and Children with Special Condition Assistance in Surakarta

Table 3. Results of the Assisting Activity Process of Sahabat Kapas to Vulnerable Children and Children with Special Condition

\begin{tabular}{|c|l|}
\hline Indicators & \multicolumn{1}{c|}{ Yayasan Sahabat Kapas } \\
\hline \multirow{5}{*}{ Input } & $\begin{array}{l}\text { 1. Vision and Mission, Roles, Strategy, Mandate. } \\
\text { 2. Assistance: } \\
\text { a. Social Capital; } \\
\text { b. Economic Capital; } \\
\text { c. Cultural Capital; } \\
\text { d. Symbolic Capital. }\end{array}$ \\
\hline \multirow{5}{*}{ Process } & $\begin{array}{l}\text { Assistance is conducted in correctional institutions/detention } \\
\text { centers/Institute for Special Development Children (LPKA) by performing } \\
\text { various activities, such as repressive socialization (delivery of material on } \\
\text { sex and reproduction), playing with the assistants, and providing } \\
\text { knowledge of entrepreneurial skills. }\end{array}$ \\
\hline Output & $\begin{array}{l}\text { 1. Children are happy in facing their future; } \\
\text { 2. Parents further enhance child care and supervision after being assisted; }\end{array}$ \\
& $\begin{array}{l}\text { 3. Increase children's confidence with the reintegration program, so that } \\
\text { there are no obstacles in socialization and growth. }\end{array}$ \\
\hline \multirow{5}{*}{ Outcome } & $\begin{array}{l}\text { 1. Post-free changes can be seen from the pattern of children's behavior to } \\
\text { be more open to parents; }\end{array}$ \\
2. Assistance is conducted to create character and education; \\
3. Coaching certifications that can be used after being released.
\end{tabular}

Source: Primary Data (2020)

\section{Conclusion}

The implementation of habitus and capital to a particular domain produces a Doxa. This Doxa is a children's trust in the correctional institutions/detention centers/Institute for Special Development Children (LPKA) for the assistants of Sahabat Kapas. The rules made by the domain are Sahabat Kapas in assisting Vulnerable Children and Children with Special Condition (Anak-Anak dalam Kondisi Khusus dan Rentan or AKKR) in correctional institutions/detention centers/Institute for Special Development Children (LPKA). According to Bourdieu, Doxa is a direct loyalty (trust and acceptance) to the rules of the game in practice between habitus and field, and which rules make the world view taken for granted (Bourdieu, 2010, pp. 120-121). In other words, agents will not see a value in a field without trust. When the agent does not have that, then the agent cannot participate in the battle in the field.

A belief arises when the assistants provide comfort and security for Vulnerable Children and Children with Special Condition in correctional institutions/detention centers/Institute for Special Development Children (LPKA). The rules that are created involve the belief in learning that continues to be good and implemented by it. These values produce information about the actions and thoughts of Vulnerable Children and Children with Special Condition in correctional institutions/detention centers/Institute for Special Development Children (LPKA). In this case, Doxa supports certain social arrangements in a field, which privileges the dominant group, the assistants of Sahabat Kapas. This position is unconsciously accepted by Vulnerable Children and Children with Special Condition in correctional institutions/detention centers/Institute for Special Development Children (LPKA). 
These regulations are knowledge of fulfilling the basic rights of children in correctional institutions/detention centers/Institute for Special Development Children (LPKA). Besides, to stay afloat and children can be met their needs need to follow the assistance conducted by the assistants of Sahabat Kapas. When one of them does not follow, then individual counseling will be charged.

\section{Acknowledgment}

The authors would like to thank Universitas Sebelas Maret for its support, facilities, and services provided during this research. The authors also would like to thank all informants who have contributed during the research process.

\section{Declaration of Conflicting Interests}

The authors have declared no potential conflicts of interest concerning the research, authorship, and/or publication of this article.

\section{References}

Badjuri, A., \& Yuwono, T. (2002). Kebijakan Publik Konsep dan Strategi. Semarang, Indonesia: Universitas Diponegoro Press.

Bourdieu, P. (2010). Dominasi Maskulin. (Stephanus Aswar Herwinarko, Trans). Yogyakarta, Indonesia: Jalasutra.

Bourdieu, P. (2012). Arena Produksi Kultural: Sebuah Kajian Sosiologi Budaya. (Yudi Santosa, Trans). Yogyakarta, Indonesia: Kreasi Wacana.

Direktorat Jenderal Pemasyarakatan Kementerian Hukum dan Hak Asasi Manusia Republik Indonesia. (2020). Data Jumlah Anak Berhadapan dengan Hukum. Retrieved from http:// smslap.ditjenpas.go.id/

Fatmawati, N. I. (2020). Pierre Bourdieu dan Konsep Dasar Kekerasan Simbolik. Madani Jurnal Politik dan Sosial Kemasyarakatan, 12(1), 41-60. Retrieved from http://www.ejurnal.unisda.ac.id/index.php/MADANI/article/view/1899

Lee, M. J. (2006). Budaya Konsumen Terlahir Kembali: Arah Baru Modernitas dalam Kajian Modal, Konsumsi, dan Kebudayaan. (Nurhadi, Trans). Yogyakarta, Indonesia: Kreasi Wacana.

Miles, M. B., \& Huberman, M. (2007). Analisis Data Kualitatif: Buku Sumber tentang Metode-Metode Baru. (Tjetjep Rohendi, Trans). Jakarta, Indonesia: Rohisi.

Nurdiansyah, R. (2016). Praktik Sosial Komunitas Outsider Di Jombang. Paradigma, 4(2), 1-6. Retrived from

https://jurnalmahasiswa.unesa.ac.id/index.php/paradigma/article/view/15205

Presiden Republik Indonesia. (1990). Keputusan Presiden Republik Indonesia Nomor 36 Tahun 1990 Tentang Pengesahan Convention On The Rights Of The Child (Konvensi Tentang Hak-Hak Anak). Lembaran Negara Republik Indonesia Tahun 1990 Nomor 57. Retrieved from http:// ditjenpp.kemenkumham.go.id/arsip/ln/1990/kp36-1990.pdf

Republik Indonesia. (2014). Undang-Undang Republik Indonesia Nomor 35 Tahun 2014 Tentang Perubahan Atas Undang-Undang Nomor 23 Tahun 2002 Tentang Perlindungan Anak. Lembaran Negara Republik Indonesia Tahun 2014 Nomor 297. Retrieved from https://jdih.setneg.go.id/viewpdfperaturan/P14748/UU\%20Nomor\%2035\%20Tahun\%20 2014

Ritzer, G., \& Goodman, D. J. (2003). Teori Sosiologi Modern (6 ed.). (Alimandan, Trans.) Jakarta, Indonesia: Kencana Prenada Media. 
Ritzer, G., \& Goodman, D. J. (2012). Teori Sosiologi Klasik - Post Moderen Edisi Terbaru. (Nurhadi, Trans.) Yogyakarta, Indonesia: Kreasi Kencana.

Ritzer, G., \& Goodman, D. J. (2014). Teori Sosiologi Modern (7th ed.). Yogyakarta, Indonesia: Kreasi Kencana.

Sahabat Kapas. (2015, July 7). Sekolah Ini, Sekolah Warga. Retrieved from https:/ / sahabatkapas.org/sekolah-ini-sekolah-warga/

Sahabat Kapas. (2019a, February 21). Our Works. Retrieved from https:/ / sahabatkapas.org/en/our-works/

Sahabat Kapas. (2019b, February 26). About Us. Retrieved from https:/ / sahabatkapas.org/en/about-us/

United Nations. (1989). OHCHR | Convention on the Rights of the Child. Retrieved from https://www.ohchr.org/en/professionalinterest/pages/crc.aspx

\section{About the Authors}

1. Nurul Istiqomah, a graduate student at Master of Sociology, Faculty of Social and Political Sciences, Universitas Sebelas Maret, Indonesia.

E-Mail: nuriesqomah@gmail.com

2. Bagus Haryono, obtained his Doctoral degree from Universitas Negeri Yogyakarta, Indonesia, in 2011. The author is an Associate Professor at the Department of Sociology, Faculty of Social and Political Sciences, Universitas Sebelas Maret, Indonesia.

E-Mail: bagusharyono@staff.uns.ac.id

3. Argyo Demartoto, obtained his Doctoral degree from Universitas Gadjah Mada, Indonesia, in 2012. The author is an Associate Professor at the Department of Sociology, Faculty of Social and Political Sciences, Universitas Sebelas Maret, Indonesia.

E-Mail: argyodemartoto_fisip@staff.uns.ac.id 